\title{
Nitrative and oxidative DNA damage in infection-related carcinogenesis in relation to cancer stem cells
}

\author{
Shosuke Kawanishi $i^{*}$, Shiho Ohnishi ${ }^{1}$, Ning Ma², Yusuke Hiraku³ ${ }^{3}$ Shinji Oikawa ${ }^{3}$ and Mariko Murata ${ }^{3}$
}

\begin{abstract}
Infection and chronic inflammation have been recognized as important factors for carcinogenesis. Under inflammatory conditions, reactive oxygen species (ROS) and reactive nitrogen species (RNS) are generated from inflammatory and epithelial cells, and result in the formation of oxidative and nitrative DNA lesions, such as 8-oxo-7,8-dihydro-2'deoxyguanosine (8-oxodG) and 8-nitroguanine. The DNA damage can cause mutations and has been implicated in inflammation-mediated carcinogenesis. It has been estimated that various infectious agents are carcinogenic to humans (IARC group 1), including bacterium Helicobacter pylori (H. pylori), viruses [hepatitis B virus ( $\mathrm{HBV}$ ), hepatitis C virus (HCV), human papillomavirus (HPV) and Epstein-Barr virus (EBV)] and parasites [Schistosoma haematobium (SH) and Opisthorchis viverrini (OV)]. H. pylori, HBV/HCV, HPV, EBV, SH and OV are important risk factors for gastric cancer, hepatocellular carcinoma, nasopharyngeal carcinoma, bladder cancer, and cholangiocarcinoma, respectively. We demonstrated that 8nitroguanine was strongly formed via inducible nitric oxide synthase (iNOS) expression at these cancer sites of patients. Moreover, 8-nitroguanine was formed in Oct3/4-positive stem cells in SH-associated bladder cancer tissues, and in Oct3/4and CD133-positive stem cells in OV-associated cholangiocarcinoma tissues. Therefore, it is considered that nitrative and oxidative DNA damage in stem cells may play a key role in infection-related carcinogenesis via chronic inflammation.
\end{abstract}

Keywords: 8-OHdG, 8-oxodG, 8-nitroguanine, Oxidative stress, Inflammation

Abbreviations: 8-oxodG, 8-oxo-7,8-dihydro-2'-deoxyguanosine; A1AT, Alpha-1-antitrypsin; BMDCs, Bone marrow-derived cells; CagA, Cytotoxin-associated gene A; CCA, Cholangiocarcinomas; CHC, Chronic hepatitis C; CIN, Cervical intraepithelial neoplasia; CS, Clonorchis sinensis; EBERs, EBV-encoded RNAs; EBV, Epstein-Barr virus; EGFR, Epidermal growth factor receptor; EMT, Epithelial-mesenchymal transition; eNOS, Endothelial NO synthase; H. pylori, Helicobacter pylori; HBV, Hepatitis B virus; HCV, Hepatitis C virus; HIV-1, Human immunodeficiency virus-1; HPV, Human papillomavirus; HSP70.1, Heat shock protein 70-kDa protein 1; HTLV-1, Human T-cell lymphotropic virus type 1; IARC, International Agency for Research on Cancer; IL, Interleukin; INF, Interferon therapy; iNOS, Inducible NO synthase; LMP1, Latent membrane protein 1; MALT, Mucosa-associated lymphoid tissue; MARK, Microtubule affinity-regulating kinase; nNOS, Neuronal NO synthase; NO, Nitric oxide; Nod1, Nucleotide-binding oligomerization domain protein 1; NPC, Nasopharyngeal carcinoma; $\mathrm{O}_{2}^{-}$, Superoxide; $\mathrm{ONOO}^{-}$, Peroxynitrite; OV, Opisthorchis viverrini; PAR1, Partitioningdefective 1; PI3KJAKT, Phosphoinositide 3-kinase/protein kinase B; RNS, Reactive nitrogen species; ROS, Reactive oxygen species; SH, Schistosoma haematobium; SHP2, Src homology 2 domain-containing phosphatase 2; STAT3, Signal transducer and activator of transcription-3; TNF-a, Tumor necrosis factor-a

\footnotetext{
* Correspondence: kawanisi@suzuka-u.ac.jp

${ }^{1}$ Faculty of Pharmaceutical Sciences, Suzuka University of Medical Science,

Suzuka, Mie 513-8670, Japan

Full list of author information is available at the end of the article
} 


\section{Background}

Infection and chronic inflammation have been recognized as important risk factors for carcinogenesis and malignancies [1-3]. The International Agency for Research on Cancer (IARC) has estimated that approximately $18 \%$ of cancer cases worldwide are attributable to infectious diseases caused by bacteria, viruses, and parasites [4]. Human cancer caused by infectious agents is shown in Table 1 . The following ten infectious agents have been classified as group 1 carcinogens (carcinogenic to humans) by IARC: bacterium Helicobacter pylori (H. pylori), viruses [hepatitis $B$ virus (HBV), hepatitis $\mathrm{C}$ virus (HCV), human papillomavirus (HPV), Epstein-Barr virus (EBV), human T-cell lymphotropic virus type 1 (HTLV-1) and human immunodeficiency virus-1 (HIV-1)] and parasites [Schistosoma haematobium (SH), Opisthorchis viverrini (OV) and Clonorchis sinensis (CS)] [4, 5]. Inflammation can be induced not only by chronic infection, but also by many other physical, chemical and immunological factors [6]. It has been estimated that chronic inflammation accounts for approximately $25 \%$ of human cancers [6]. Cancer risk is heavily influenced by environmental factors such as infections. $\mathrm{HPV}, \mathrm{HBV} / \mathrm{HCV}$ and $H$. pylori may be responsible for about $90 \%$ of cervical cancer cases, $80 \%$ of hepatocellular carcinoma cases and $65-80 \%$ of gastric cancer cases, respectively [7].

\section{DNA damage in inflammation-related carcinogenesis}

Under inflammatory conditions, reactive oxygen species (ROS) and reactive nitrogen species (RNS) are generated from inflammatory and epithelial cells. ROS and RNS are capable of causing damage to various cellular constituents, such as nucleic acids, proteins and lipids. ROS are generated from multiple sources, including inflammatory cells, carcinogenic chemicals and their metabolites, and the electron transport chain in mitochondria $[2,3]$. ROS can induce the formation of oxidative DNA lesion products, including 8-oxo-7,8-dihydro-2'deoxyguanosine $(8$-oxodG), which is considered to be mutagenic [8].

Nitric oxide (NO) is synthesized by NO synthases. There are three isoforms, neuronal NO synthase (nNOS, also known as NOS1), inducible NO synthase (iNOS or NOS2) and endothelial NO synthase (eNOS or NOS3) $[9,10]$. iNOS is activated to drastically generate $\mathrm{NO}$ in inflammatory and epithelial cells under inflammatory

Table 1 Human cancer caused by infectious agents worldwide and possible markers

\begin{tabular}{|c|c|c|c|c|c|}
\hline Infectious agents & Cancer site & $\begin{array}{l}\text { Number of cancer } \\
\text { cases }\end{array}$ & $\begin{array}{l}\text { Cancer cases world } \\
\text { wide }(\%)\end{array}$ & $\begin{array}{l}\text { Detection of 8-nitroguanine } \\
\text { [Refs.] }\end{array}$ & $\begin{array}{l}\text { Possible markers for } \\
\text { CSC [20] }\end{array}$ \\
\hline \multicolumn{6}{|l|}{ Bacteria } \\
\hline H. pylori & Stomach & 490,000 & 5.4 & Patients $[31,76]$ & SALL4, KLF5, LgR5 \\
\hline \multicolumn{6}{|l|}{ Viruses } \\
\hline HPV & Cervix and other sites & 550,000 & 6.1 & Patients [52] & $\begin{array}{l}\text { CK17 } \\
\text { CD44 (HPV16) } \\
\text { Oct3/4 (HPV16) }\end{array}$ \\
\hline $\mathrm{HBV}, \mathrm{HCV}$ & Liver & 390,000 & 4.3 & $\begin{array}{l}\text { Patients with HCV [39] } \\
\text { Mice with HBV [Fig. 5B, } \\
\text { unpublished data] }\end{array}$ & $\begin{array}{l}\text { CK19 } \\
\text { Nanog, CD133 }\end{array}$ \\
\hline EBV & $\begin{array}{l}\text { Lymphoma } \\
\text { Nasopharyngeal } \\
\text { carcinoma }\end{array}$ & 99,000 & 1.1 & Patients [57] & $\begin{array}{l}\text { LMP2A } \\
\text { LMP1, Bmi-1 }\end{array}$ \\
\hline HHV-8 & Kaposi sarcoma & 54,000 & 0.6 & & \\
\hline HTLV-1 & Leukemia & 9,000 & 0.1 & & \\
\hline \multicolumn{6}{|l|}{ Parasites } \\
\hline $\mathrm{SH}$ & Bladder & 2,700 & 0.1 & Patients $[21,22]$ & $\begin{array}{l}\text { Oct3/4 (patients with } \\
\text { SH) [21] } \\
\text { CD44v6 (patients } \\
\text { without SH) [22] }\end{array}$ \\
\hline Liver flukes & Cholangiocarcinoma & 800 & & & \\
\hline OV & & & & $\begin{array}{l}\text { Hamsters }[68-70,75] \\
\text { Patients }[71,74]\end{array}$ & CD133, Oct3/4 [74] \\
\hline \multicolumn{6}{|l|}{ CS } \\
\hline & $\begin{array}{l}\text { Total infection- related } \\
\text { cancers }\end{array}$ & $1,600,000$ & 17.7 & & \\
\hline & Total cancers in 1995 & $9,000,000$ & 100 & & \\
\hline
\end{tabular}


conditions, while eNOS and nNOS are constitutively expressed and produce relatively small amounts of NO. iNOS can be also up-regulated by transcription factors such as NF-kB, HIF-1 $\alpha$, STAT, tumor necrosis factor- $\alpha$ $(\mathrm{TNF}-\alpha)$. NF-kB plays a central role in inflammation through its ability to induce transcription of proinflammatory genes, including iNOS, and functions as a tumor promoter in inflammation-associated cancer [11].

Figure 1 shows 8-nitroguanine formation under inflammatory conditions and resulting mutation. $\mathrm{NO}$ reacts with superoxide $\left(\mathrm{O}_{2}^{-}\right)$to form peroxynitrite $\left(\mathrm{ONOO}^{-}\right)$, a highly reactive species causing 8-oxodG and 8-nitroguanine [12]. The reaction of guanine with $\mathrm{ONOO}^{-}$forms 8nitroguanine as the major compound, while adenine nitration is minor compared to its C8-oxidation [13]. The glycosidic bond between 8-nitroguanine and deoxyribose is chemically unstable, and this DNA lesion can be spontaneously released, resulting in the formation of an apurinic site [14]. The apurinic site can form a pair with adenine during DNA synthesis, leading to $\mathrm{G}: \mathrm{C}$ to $\mathrm{T}: \mathrm{A}$ transversions [15]. In addition, translesion DNA polymerases were discovered and their role in the mutagenesis has been investigated [16]. Cells deficient in Rev1 and Rev3, subunits of DNA polymerase $\zeta$, were hypersensitive to nitrative stress, and translesion DNA synthesis past apurinic sites mediated by this polymerase might contribute to extensive point mutations [17]. It has been reported that adenine is preferentially incorporated opposite 8-nitroguanine during DNA synthesis catalyzed by polymerase $\eta$ and a truncated form of polymerase kin a cell-free system, suggesting that G:C to T:A transversions can occur [18].

8-Nitroguanine is considered to be not only a marker of inflammation, but also a potential mutagenic DNA lesion involved in carcinogenesis [19]. We have investigated the formation of 8-nitroguanine and 8-oxodG in various clinical specimens and animal models in relation to inflammation-related carcinogenesis, as summarized in Table 1. When specimens or cultured cells were pretreated with RNase, 8-nitroguanine was more clearly observed in the nuclei of cells by immunostaining. It suggests that 8-nitroguanine is formed mainly in genomic DNA. It is noteworthy that nitrative and oxidative DNA lesions were specifically induced at cancer sites under chronic infection and various inflammatory conditions, as reviewed previously $[2,3,20]$. We demonstrated that 8-nitroguanine was strongly formed via iNOS expression at related cancer sites of $H$. pylori, HBV, HCV, HPV, EBV and SH, OV [2, 3, 21, 22]. The IARC classification of $\mathrm{CS}$ has been recently updated from $2 \mathrm{~A}$ to 1 , so we have not yet collected enough data for 8-nitroguanine.

Nitrative and oxidative stresses cause DNA damage, contributing to the accumulation of mutations in tissues throughout the carcinogenic process. Particularly, 8nitroguanine formation may participate in inflammationrelated carcinogenesis as a common mechanism. Therefore, 8-nitroguanine could be used as a potential biomarker of inflammation-related carcinogenesis.

\section{Cancer stem cell markers in inflammation-related carcinogenesis}

The cancer stem cell concept is widely accepted as important for overcoming cancer [23]. Several studies have revealed that cancer stem cells show accumulation of mutations, genetic instability and epigenetic change suggesting that cancer is also a disease of genes. The most important question is how to generate cancer stem cells. Recently, many studies have been reported on the expressions of stemness cell markers in various kinds of cancer. Table 1 summarizes possible markers of cancer stem cells, especially related to each inflammatory causative agent [20]. We reported that 8-nitroguanine was strongly formed at all of these cancer sites from animals and patients with infectious agents. Importantly, we also detected co-localization of 8-nitroguanine and stemness marker in infection-related carcinogenesis, as mentioned in the next section. On the basis of our recent studies, it is considered that chronic inflammation can increase mutagenic DNA lesions through ROS/RNS generation and can promote proliferation via stem cells activation for tissue regeneration (Fig. 2). This idea is also supported by other papers about the association of cancer stem cells with infection and inflammation [24, 25].

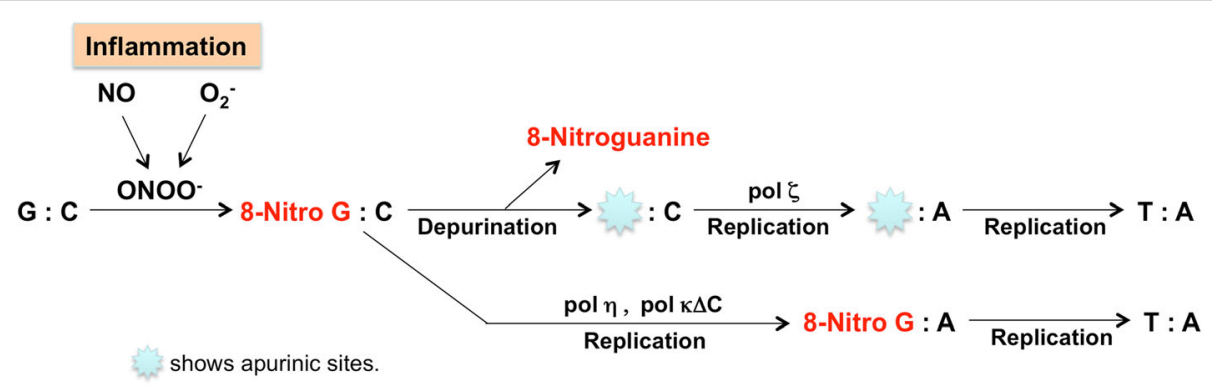

Fig. 1 Proposed mechanism of mutation mediated by 8-nitroguanine formation 


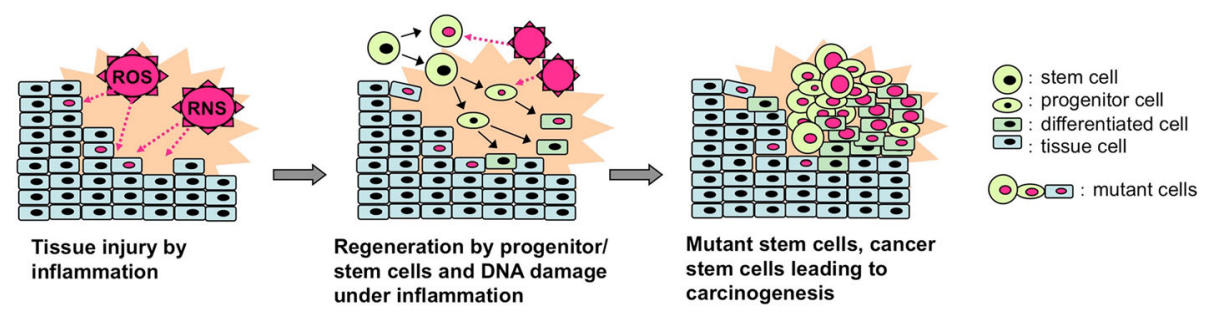

Fig. 2 Possible mechanism for generating mutant stem cells by inflammation

\section{H. pylori infection and gastric cancer}

The presence of the Gram-negative bacterium, H. pylori is associated with not only chronic atrophic gastritis and peptic ulcer but also gastric adenocarcinoma and nonHodgkin's lymphoma [mucosa-associated lymphoid tissue (MALT) lymphoma] [26]. H. pylori may be responsible for 65-80 \% of gastric cancer cases [27]. The mechanisms by which $H$. pylori infection causes gastric cancer have been investigated (Fig. 3). Cytotoxin-associated gene A (CagA) protein is delivered into gastric epithelial cells, and mediates activation of Src homology 2 domain-containing phosphatase 2 (SHP2) tyrosine phosphatase by specifically binding and conformation change, resulting to abnormal proliferation and promotion of cell motility [28]. CagA also play a role in disruption of construction of gastric mucosa by interacting with and inhibiting partitioningdefective 1 (PAR1)/microtubule affinity-regulating kinase (MARK) [29]. Peptidoglycan has been described as a possible factor inducing nucleotide-binding oligomerization domain protein 1 (Nod1)-mediated NF-kB signaling, which can induce iNOS expression [30].

We performed a double immunofluorescence labeling study and demonstrated that the intense immunoreactivities of 8-nitroguanine and 8-oxodG were observed both in gastric gland epithelial cells and inflammatory cells in patients with $H$. pylori infection (Fig. 4, upper panels) [31]. Moreover, these immunoreactivities were decreased after eradication (Fig. 4, lower panels). It has been reported that the expression of iNOS was significantly increased in $H$. pylori-positive gastritis compared to H. pylori-negative gastritis [32]. These suggest that nitrative and oxidative DNA damage in gastric epithelial cells and their proliferation by $H$. pylori infection may lead to gastric carcinoma.

There are several papers concerning the relation of cancer stem cells in $H$. pylori induced carcinogenesis. H. pylori colonize and manipulate the progenitor and stem cell components, which alters turnover kinetics and glandular hyperplasia [33]. H. pylori infection and inflammation leads to an epithelial-mesenchymal transition (EMT) and altered tissue regeneration and differentiation from both local epithelial stem cells and bone marrow-derived cells (BMDCs) [34]. These abilities to alter the stem cells may be involved in generating cancer stem cells, in addition to mutagenic DNA damage.

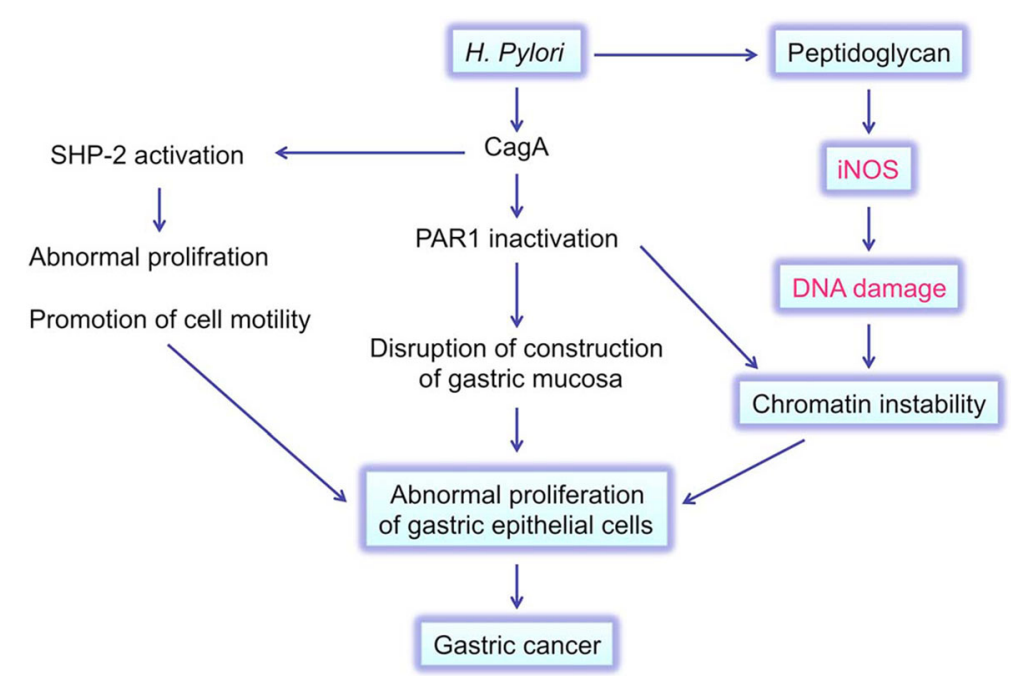

Fig. 3 Mechanism of carcinogenesis induced by H. pylori infection 


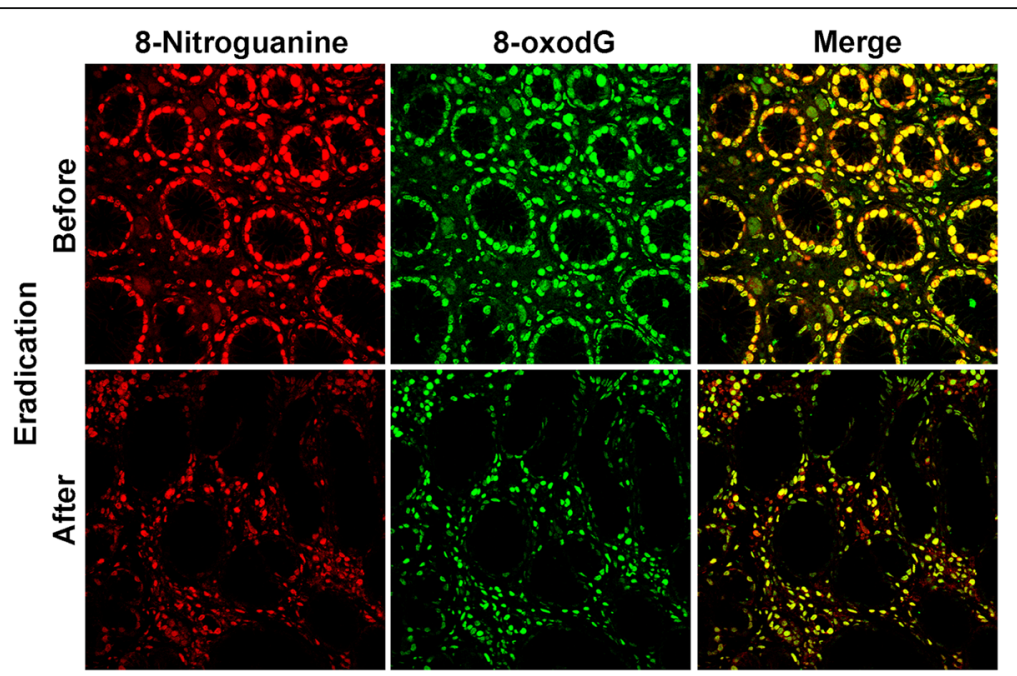

Fig. 4 8-Nitroguanine and 8-oxodG formation in gastritis patients with H. pylori infection. Double immunofluorescence staining of paraffin sections shows the localization of 8-nitroguanine (red) and 8-oxodG (green) in the gastric epithelium. Yellow colour in right panels (Merge) shows co-localization of 8-nitroguanine and 8-oxodG

\section{$\mathrm{HBV}$ or HCV infection and liver cancer}

$\mathrm{HBV}$ or $\mathrm{HCV}$ is a major cause of chronic hepatitis, liver cirrhosis, and hepatocellular carcinoma throughout the world [35, 36]. HBV / HCV may account for about $80 \%$ of hepatocellular carcinoma cases $[37,38]$. It is generally accepted that hepatocellular carcinoma arises through a multistep process of genetic alterations in hepatocytes during chronic hepatitis $\mathrm{C}(\mathrm{CHC})$. However, the mechanism of $\mathrm{HCV}$ infection-induced hepatitis followed by hepatocarcinogenesis via DNA damage is still unclear.

We investigated DNA damage in liver biopsy specimens of patients with $\mathrm{CHC}$ and the effect of interferon treatment. Immunoreactivities of 8-nitroguanine and 8oxodG were strongly detected in the liver from patients with $\mathrm{CHC}$ in Fig. 5 [39]. 8-Nitroguanine accumulation was found in not only infiltrating inflammatory cells but also hepatocytes particularly in the periportal area. The accumulation of 8-nitroguanine and 8-oxodG increased with inflammatory grade. iNOS expression was observed in the cytoplasm of hepatocytes and Kupffer cells in $\mathrm{CHC}$ patients [39]. In the sustained virological responder group after interferon therapy (+INF in Fig. 5a), the accumulation of 8-nitroguanine and 8-oxodG in the liver was markedly decreased [39]. Our results are consistent with the previous reports showing that the expression of iNOS in hepatocytes has been observed in patients with chronic hepatitis [40] and hepatocellular carcinoma [41]. Moreover, we demonstrated the accumulation of 8-nitroguanine and expression of iNOS in liver tissues of mice infected with HBV (Fig. 5). Taken together, these findings indicate that 8-nitroguanine is a useful biomarker to evaluate the severity of $\mathrm{HBV} / \mathrm{HCV}$ induced chronic inflammation leading to hepatocellular carcinoma.

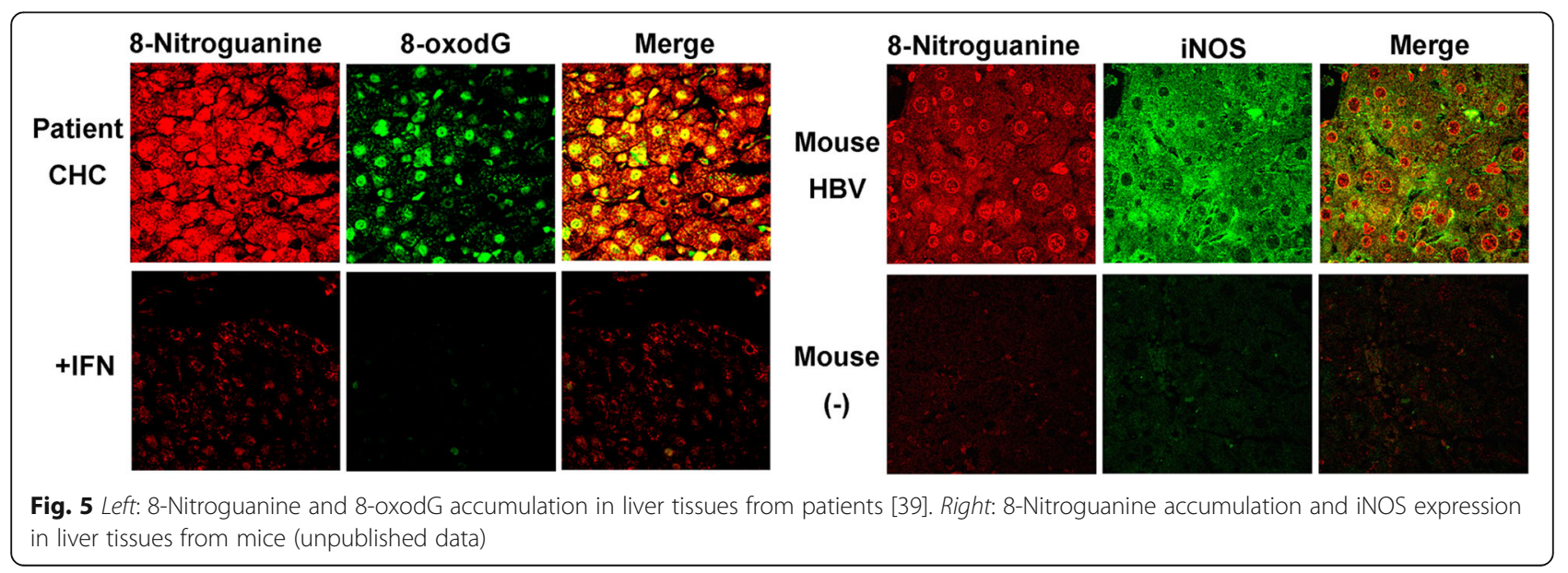


It has been reported that hepatic progenitor cells increase in the liver of $\mathrm{HCV}$ patients as the disease advances to cirrhosis, while CD133 (stem/progenitor cell marker) -positive cancer stem cells correlated with early recurrence and poor prognosis among $\mathrm{HBV}$ related HCC patients [38]. HBV/HCV modulate hypoxic pathways to adapt cells in hypoxic conditions conferring EMT characteristics [38]. Hypoxia sustains the self-renewal characteristics of a portion of cancer cells in hypoxic niches mainly due to the upregulation of Oct4, NANOG, SOX2, Klf4, and c-myc [38]. It is necessary to study whether 8-nitroguanine forms in cancer stem cells.

\section{Human papillomavirus and cervical cancer}

Cervical cancer is the fourth most common cancer among women worldwide and approximately $70 \%$ of the cases occur in developing countries [42]. HPV may cause about $90 \%$ of cervical cancer cases [43]. Virtually all cases of cervical cancer are attributable to persistent infection with HPV [44]. IARC has evaluated several high-risk types of HPV, including HPV-16, 18, 31, 33, $35,39,45,51,52,56,58$ and 59 , to be carcinogenic to humans (group 1) $[45,46]$. HPV infection is a necessary event that precedes the development of cervical intraepithelial neoplasia (CIN), a premalignant lesion, which partially progresses to cancer [47]. Figure 6 shows a schematic diagram of HPV-induced carcinogenesis. E6 and E7 participate in HPV-induced carcinogenesis by inactivating the tumor suppressor gene products, p53 and $\mathrm{Rb}$, respectively. E6 and E7 expression is necessary but not sufficient to transform the host cell, as genomic instability is required to acquire the malignant phenotype in HPV-initiated cells. Recently, Marullo et al. reported that HPV16 E6 and E7 proteins induced a chronic oxidative stress, to cause genomic instability and increased susceptibility to DNA damage [48]. In addition, inflammation-mediated DNA damage may be involved in cervical carcinogenesis.

Although it is unclear whether HPV infection alone induces the inflammatory responses, epidemiological studies have suggested that cervical inflammation in HPV-infected women is associated with cervical neoplasia $[47,49]$. Co-infection with HPV and other pathogens increase the risk of cervical cancer. Among HPV DNApositive women, infection with herpes simplex virus-2 is associated with the risk of invasive cervical carcinoma. Molecular epidemiological studies have shown that COX-2 is overexpressed in cervical cancer [50, 51]. These findings suggest that inflammation plays a substantial role in HPV-mediated carcinogenesis.

To clarify the role of inflammation-mediated DNA damage in cervical carcinogenesis, we examined 8nitroguanine formation in cervical biopsy specimens of patients obtained from HPV-infected patients. We compared the extent of 8-nitroguanine formation in patients with different stages of CIN caused by high-risk HPV and condyloma acuminatum, benign cervical warts caused by low-risk HPV. 8-Nitroguanine was formed in the nuclei of atypical epithelial cells of CIN patients but not in condyloma acuminatum patients. Statistical analysis revealed that the staining intensity of 8-nitroguanine was significantly increased in the order of condyloma acuminatum $<$ CIN1 < CIN2-3 [52]. Inflammation-mediated DNA damage, which precedes the genomic abnormalities caused by HPV oncoproteins, may play an important role in carcinogenesis.

The formation of nitrative DNA lesion during cervical carcinogenesis has been supported by a recent study.

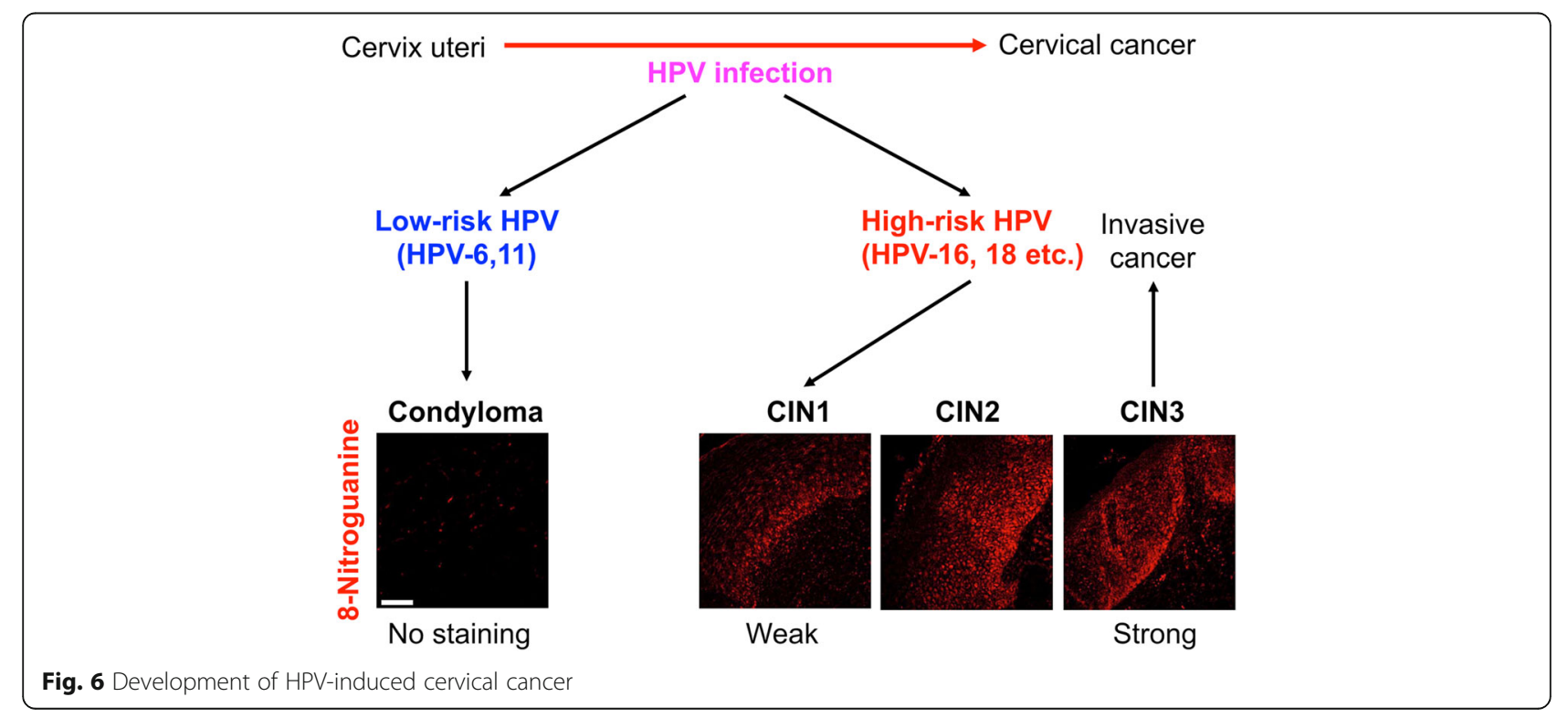


NO induced DNA damage and increased mutation in HPV-positive human cervical epithelial cell lines established from CIN patients [53]. In addition, NO increased the expression of E6 and E7 genes, resulting in decreased p53 and RB protein levels in these cells [53]. These findings raise the possibility that NO-mediated DNA damage and viral oncoproteins cooperatively contribute to HPV-induced cervical carcinogenesis (Fig. 7).

López et al. reviewed human papillomavirus infections and cancer stem cells of tumors from the uterine cervix [54]. Stem cell associated proteins including human chorionic gonadotropin, the oncogene TP63 and the transcription factor SOX2 were upregulated in samples from women with CIN3 [55]. The stem cell related, cell surface protein podocalyxin was detectable on cells in samples from a subset of women with CIN3. SOX2 and TP63 proteins clearly delineated tumour cells in invasive squamous cervical cancer [55].

\section{Epstein-Barr virus and nasopharyngeal carcinoma}

Lymphomas, gastric cancer and nasopharyngeal carcinoma (NPC) are strongly associated with EBV infection, and account for approximately $1 \%$ of cancer cases worldwide [4]. NPC has a profoundly skewed geographical incidence, being common in the arctic (Inuits and Aleuts), North Africa, and South East Asia [56]. The remarkably higher incidence of NPC among the Chinese, especially in South China and South Eastern Asia is mainly attributed to the non-keratinizing subtype, which has a virtually $100 \%$ association with EBV $[4,56]$.

We examined 8-nitroguanine and 8-oxodG formation in biopsy specimens from patients with nasopharyngitis and NPC in southern China. 8-Nitroguanine and 8oxodG were formed in epithelial cells of EBV-positive patients with chronic nasopharyngitis, and their intensities were significantly stronger in cancer cells of NPC patients [57]. The serum level of 8-oxodG in NPC patients was significantly higher than control patients, suggesting the involvement of oxidative stress [58]. We confirmed EBV infection at the nasopharyngeal tissues by using in situ hybridization for EBV-encoded RNAs (EBERs). Also, a viral protein latent membrane protein 1 (LMP1) was detected in cancer cells from all EBVinfected patients. LMP1 induces the expression and nuclear accumulation of epidermal growth factor receptor (EGFR), which in turn interacts with the signal transducer and activator of transcription-3 (STAT3) in the nucleus, leading to transcriptional activation of iNOS [59]. In our study, intensive immunoreactivity of iNOS was detected in the cytoplasm of cancer cells, and EGFR and phosphorylated STAT3 were strongly expressed in cancer cells of NPC patients. Interleukin (IL)- 6 was expressed in macrophages of nasopharyngeal tissues of EBV-infected patients. EGFR was accumulated in the nucleus of LMP1-expressing cells, and the addition of IL-6 induced the expression of phosphorylated STAT3 and iNOS and the formation of inflammation-related DNA lesions $[3,57]$. The proposed mechanism of EBVinduced carcinogenesis (Fig. 8), that is, EBV infection may induce nuclear accumulation of EGFR and IL-6mediated STAT3 activation, leading to iNOS expression and formation of 8-nitroguanine and 8-oxodG.

Recently interesting study has been reported [60]. EBVencoded LMP1 could induce development of CD44-positive stem-like cells in NPC. LMP1 activated and triggered phosphoinositide 3-kinase/protein kinase B (PI3K/AKT) pathway, which subsequently stimulated expression of $\mathrm{CD} 44$, development of side population and tumor sphere formation.

\section{DNA damage and mutant stem cells induced by Schistosoma haematobium infection}

Chronic infection with $\mathrm{SH}$ is associated with urinary bladder cancer, especially in the Middle East and Africa [61]. Contact with contaminated river water is the major risk factor for infection. It is believed that the parasite's eggs in the host bladder result in irritation, eventual fibrosis and chronic cystitis, leading to carcinogenesis. We

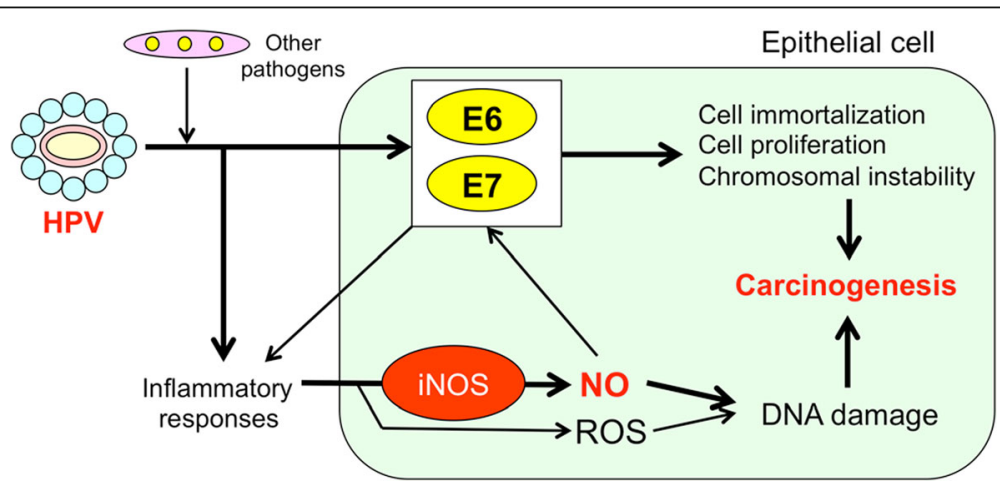

Fig. 7 Possible mechanisms of HPV-induced cervical carcinogenesis 


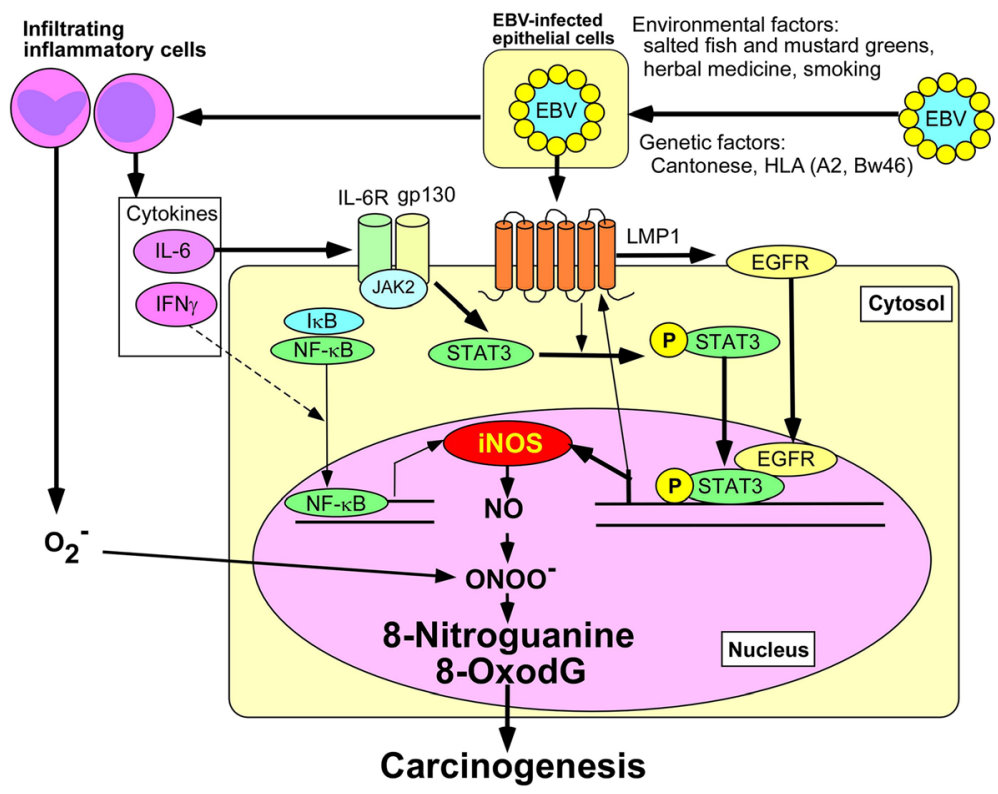

Fig. 8 Proposed mechanism of EBV-induced carcinogenesis

demonstrated for the first time that 8-nitroguanine is formed in the tumors of bladder cancer patients with SH infection, by immunohistochemical analysis [21]. The formation of 8-nitroguanine and 8-oxodG was significantly higher in bladder cancer and cystitis tissues than in normal tissues. iNOS expression was colocalized with NF-kB in 8-nitroguanine-positive tumor cells from bladder cancer patients. NF-kB can be activated by TNF- $\alpha$, a major mediator of inflammation, stimulated by $\mathrm{SH}$ egg antigen. These suggest that both 8-nitroguanine and 8-oxodG are formed by iNOSmediated NO overproduction via NF-kB activation, under $\mathrm{SH}$-caused chronic inflammation.

A stemness marker, Oct3/4, is necessary for maintaining the self-renewing, cancer stem-like, and chemoradioresistant properties of tumorigenic stem-like cell populations $[62,63]$, and is thus considered to play roles in the carcinogenesis process. Another stemness marker, CD44, has been identified as a cell surface marker associated with cancer stem cells in tumors $[64,65]$, including urinary bladder cancer. Expression of CD44v6, a splicing variant of $\mathrm{CD} 44$, is correlated with proliferation of poorly differentiated urothelial cells and the characteristic phenotype of tumor-initiating bladder cancer stem cells $[66,67]$. Our previous reports have showed that $\mathrm{SH}$-induced urinary bladder cancer correlates with the expression of Oct3/4 [21], while urinary bladder cancer without the infection correlates with the expression of CD44v6 [22]. It is noteworthy that different risk factors induce different levels of expression of stemness markers in urinary bladder carcinoma. Moreover, 8- nitroguanine was formed in Oct3/4-positive stem cells in $\mathrm{SH}$-associated cystitis and cancer tissues as shown in Fig. 9 [21]. Inflammation by SH infection may increase the number of mutant stem cells, in which iNOSdependent DNA damage occurs via NF-kB activation, leading to tumor development.

\section{DNA damage and mutant stem cells induced by OV infection}

Chronic infection with the liver flukeOV is associated with cholangiocarcinomas (CCA) [5]. Repeated intake of raw fish containing the infective stage of $\mathrm{OV}$ is a cause of the parasite-induced CCA. Re-infection with OV is a major risk factor of CCA in northeast Thailand. We assume that $\mathrm{OV}$-associated CCA is one of a model of inflammationmediated carcinogenesis. We demonstrated 8-nitroguanine and 8-oxodG formation in the bile duct of hamsters fed with metacercariae of OV [68-70]. These DNA lesions were observed in inflammatory cells and epithelium of bile ducts, and their formation increased in a manner dependent on infection times. The anthelminthic drug praziquantel dramatically diminished the DNA lesions and iNOS expression in OV-infected hamsters. Thus, repeated OV-infection can induce the iNOS-dependent nitrative and oxidative damage to nucleic acids in bile ducts via NF- $k$ B expression, which may participate in CCA.

In our study with patients, the formation of 8-oxodG and 8-nitroguanine occurred to a much greater extent in cancerous tissues than in non-cancerous tissues in CCA patients, indicating that these DNA lesions contribute to 


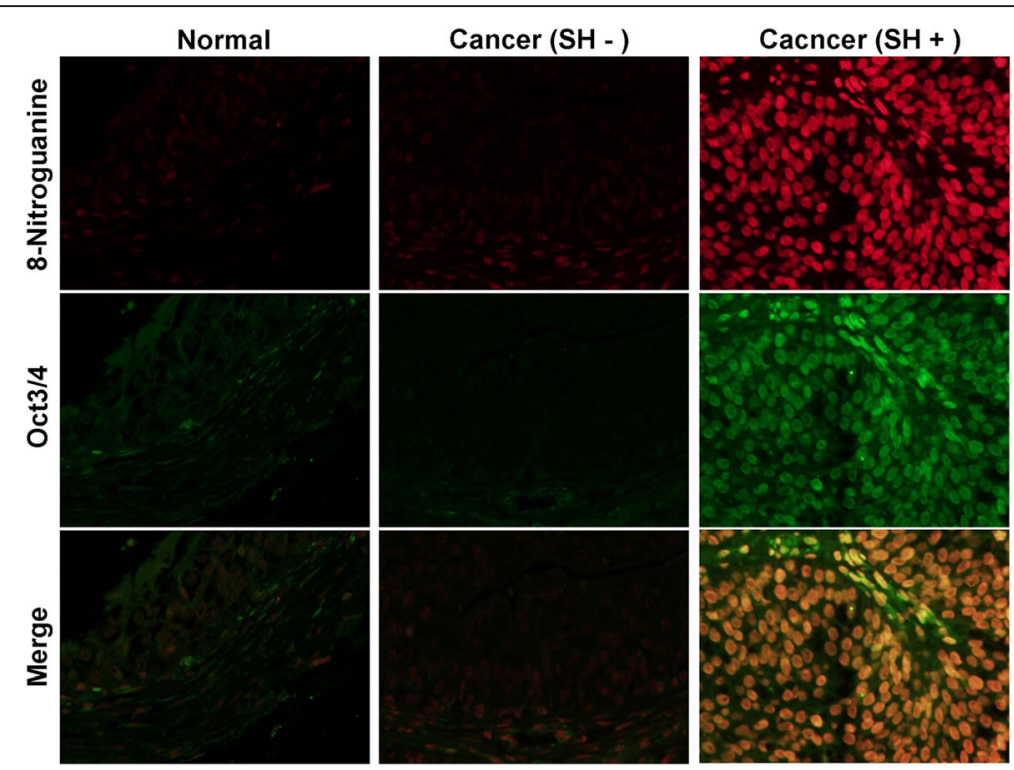

Fig. 9 Formation of 8-nitroguanine and expression of Oct3/4 in bladder tissues. The formation of 8-nitroguanine (red) and the expression of Oct3/4 (green) were assessed by double immunofluorescence staining [21]. In the merged image, co-localization of 8-nitroguanine and Oct3/4 is indicated in yellow. Biopsy and surgical specimens were obtained from normal subjects and patients with SH-induced cystitis and bladder cancer. Normal tissues and urinary bladder cancer tissues without SH-infection were obtained from a commercial urinary bladder tissue array (Biomax.uS, USA)

tumor initiation [71]. Urinary 8-oxodG levels were significantly higher in CCA patients than in OV-infected patients, and higher in OV-infected subjects than in healthy subjects. The urinary 8-oxodG levels in OV-infected patients significantly decreased two months after praziquantel treatment [72].

Our study with proteomics approach showed that oxidation of serotransferrin, alpha-1-antitrypsin (A1AT) and heat shock protein $70-\mathrm{kDa}$ protein 1 (HSP70.1) were significantly associated with poor prognoses [73]. HSP70.1 acts as a molecular chaperone to protect various cells from oxidative stress. A1AT, a glycoprotein, is a member of the serpins (serine protease inhibitors), inhibitors of a wide variety of proteases in relation to tumor invasion. Serotransferrin (transferrin) is an iron $\left(\mathrm{Fe}^{3+}\right)$-binding and -transporting protein. Interestingly, we observed that serotransferrin was highly expressed and co-localized with iron in the tumor, suggesting iron accumulation and its release from oxidatively-damaged serotransferrin. We have proposed that oxidative damage of serotransferrin, HSP70.1 and A1AT may induce oxidative stress by ironaccumulation and dysfunction of anti-oxidative and antiinvasive properties, leading to increased oxidative DNA damage and progression of CCA.

Recently, we observed high expression and colocalization of hepatocyte marker and cholangiocyte marker in $\mathrm{OV}$-associated CCA patients, suggesting the involvement of stem cells in CCA development [74]. Stem/progenitor cell markers (CD133 and OV6) were positively stained in CCA cases (Fig. 10). Quantitative analysis of 8-oxodG revealed significantly increased levels in CD133- and/or Oct3/4-positive tumor tissues compared to negative tumor tissues, suggest that CD133 and Oct $3 / 4$ in CCA are associated with increased formation of DNA lesions [74]. Moreover, CD133- and Oct3/ 4-positive CCA patients had significant associations with poor prognoses. These findings suggest that CD133 and Oct3/4 in CCA are highly associated with formation of DNA lesions, which may be involved in mutant stem

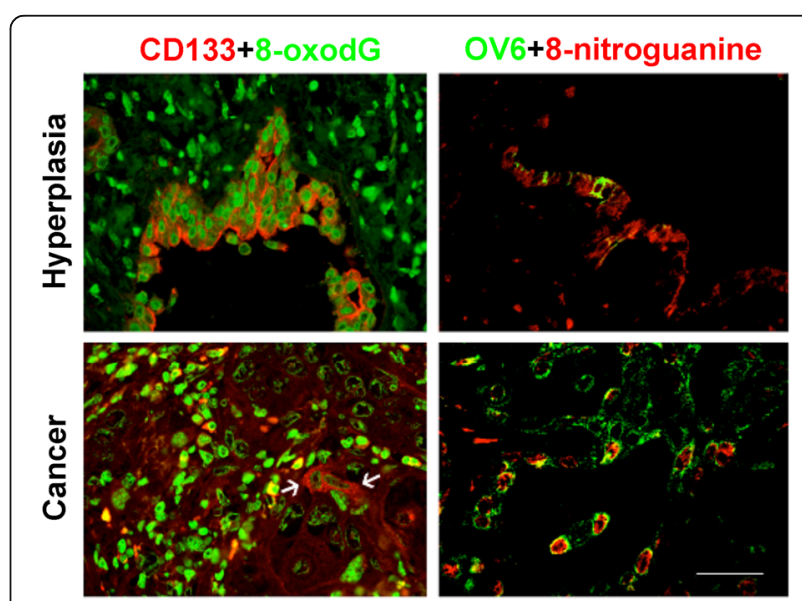

Fig. 10 Colocalization of stem cell markers and DNA damage. Doubleimmunofluorescence staining of stem/progenitor cell markers (CD133 and OV6) and DNA lesions (8-oxodG and 8-nitroguanine) in cholangiocarcinoma tissues. White arrows indicate co-localization of DNA damage marker and stemness marker in cancer cells. Original magnification is $\times 400$; Scale bar $=25 \mu \mathrm{m}$ 
cells, leading to cancer stem cells. Inflammation by OV infection may increase the number of mutant stem cell under oxidative and nitrative stresses, and the mutant stem cell proliferation may promote to be cancer stem cells of CCA.

\section{Conclusions}

Nitrative and oxidative DNA lesions with mutagenic properties are formed in various types of inflammation-related cancer tissues. We have proposed a mechanism for the generation of cancer stem cells by inflammation in Fig. 2 . Chronic inflammation by infectious agents, inflammatory diseases, and other factors causes various types of damage to nucleic acids, proteins, tissue and so on, via ROS/RNS generation. Tissue injury under chronic inflammation may activate progenitor/stem cells for regeneration. In these cells, ROS/RNS from inflammation can cause multiple mutations, which may generate mutant stem cells and cancer stem cells, leading to carcinogenesis. Indeed, 8nitroguanine was formed in stemness marker-positive cells in parasite-associated cancer tissues. The mechanism for generation of cancer stem cells will be explained by our ongoing studies on the formation of 8-nitroguanine in stem-like cells of target tissues associated with other inflammation-related cancers.

\section{Acknowledgments}

SK is funded by Grant-in-Aid for Scientific Research (C) (15 K08787), Japan Society for the Promotion of Science (JSPS), The Ministry of Education, Culture, Sports, Science and Technology (MEXT), Japan. SO is funded by Grant-in-Aid for Scientific Research (C) (26460813), Japan Society for the Promotion of Science (JSPS), The Ministry of Education, Culture, Sports, Science and Technology (MEXT), Japan. No conflict of interest statement is declared.

\section{Funding}

This work was partly supported by a Grant-in-Aid from the Ministry of Education, Culture, Sports, Science and Technology of Japan (Grant Numbers $15 \mathrm{~K} 08787,26460813)$.

\section{Availability of data and materials}

This review does not include new relevant raw data. We removed identifying information from all tissue samples. See, references for original data; $H$. pylori [31], HPV [52], HBV/HCV [39], EBV [57], SH [21, 22], OV [71, 74, 75].

\section{Authors' contributions}

SK conceived of the design of the study. All authors participated to draft, read and approve the final manuscript.

\section{Competing interests}

The authors declare that they have no competing interests.

\section{Consent for publication}

Not applicable.

\section{Ethics approval and consent to participate}

Studies in this review have been performed in accordance with the Declaration of Helsinki and approved by appropriate ethics committees. All animal experiments except for OV infection were carried out according to the protocol approved by the Ethics Committee for Animal Experiments at Mie University School of Medicine. See references for details; H. pylori [31], HPV [52], HBV/HCV [39], EBV [57], SH [21, 22], OV $[71,74,75]$.

\section{Author details}

${ }^{1}$ Faculty of Pharmaceutical Sciences, Suzuka University of Medical Science, Suzuka, Mie 513-8670, Japan. ${ }^{2}$ Faculty of Nursing, Suzuka University of Medical Science, Suzuka, Mie 513-8670, Japan. ${ }^{3}$ Department of Environmental and Molecular Medicine, Mie University Graduate School of Medicine, Tsu, Mie 514-8507, Japan.

Received: 2 April 2016 Accepted: 27 July 2016

Published: 1 January 2017

\section{References}

1. Coussens LM, Werb Z. Inflammation and cancer. Nature. 2002;420(6917): 860-7.

2. Kawanishi S, Hiraku Y. Oxidative and nitrative DNA damage as biomarker for carcinogenesis with special reference to inflammation. Antioxid Redox Signal. 2006;8(5-6):1047-58.

3. Murata M, Thanan R, Ma N, Kawanishi S. Role of nitrative and oxidative DNA damage in inflammation-related carcinogenesis. J Biomed Biotechnol. 2012; 2012:623019. doi:10.1155/2012/623019.

4. IARC. Chronic infections. In: Stewart BW, Kleihues P, editors. World Cancer Report. Lyon: IARC Press; 2008. p. 128-35.

5. IARC. Opisthorchis viverrini and clonorchis sinensis. In: IARC monographs on the evaluation of carcinogenic risks to humans "a review of human carcinogens: biological agents." vol. 100B. Lyon: IARC Press; 2012. p. 347-76.

6. Hussain SP, Harris CC. Inflammation and cancer: an ancient link with novel potentials. Int J Cancer. 2007;121(11):2373-80

7. Wu S, Powers S, Zhu W, Hannun YA. Substantial contribution of extrinsic risk factors to cancer development. Nature. 2016;529(7584):43-7. doi:10.1038/ nature16166.

8. Kawanishi S, Hiraku Y, Oikawa S. Mechanism of guanine-specific DNA damage by oxidative stress and its role in carcinogenesis and aging. Mutat Res. 2001;488(1):65-76.

9. Fukumura D, Kashiwagi S, Jain RK. The role of nitric oxide in tumour progression. Nat Rev Cancer. 2006;6(7):521-34.

10. Lala PK, Chakraborty C. Role of nitric oxide in carcinogenesis and tumour progression. Lancet Oncol. 2001;2(3):149-56.

11. Wang S, Liu Z, Wang L, Zhang X. NF-kappaB signaling pathway, inflammation and colorectal cancer. Cell Mol Immunol. 2009;6(5):327-34. doi:10.1038/cmi.2009.43.

12. Halliwell B. Oxygen and nitrogen are pro-carcinogens. Damage to DNA by reactive oxygen, chlorine and nitrogen species: measurement, mechanism and the effects of nutrition. Mutat Res. 1999;443(1-2):37-52.

13. Sodum RS, Fiala ES. Analysis of peroxynitrite reactions with guanine, xanthine, and adenine nucleosides by high-pressure liquid chromatography with electrochemical detection: C8-nitration and -oxidation. Chem Res Toxicol. 2001:14(4):438-50.

14. Yermilov V, Rubio J, Ohshima H. Formation of 8-nitroguanine in DNA treated with peroxynitrite in vitro and its rapid removal from DNA by depurination. FEBS Lett. 1995;376(3):207-10.

15. Loeb LA, Preston BD. Mutagenesis by apurinic/ apyrimidinic sites. Annu Rev Genet. 1986;20:201-30.

16. Sale JE, Lehmann AR, Woodgate R. Y-family DNA polymerases and their role in tolerance of cellular DNA damage. Nat Rev Mol Cell Biol. 2012;13(3):14152. doi:10.1038/nrm3289.

17. Wu X, Takenaka K, Sonoda E, Hochegger H, Kawanishi S, Kawamoto T, Takeda S, Yamazoe M. Critical roles for polymerase zeta in cellular tolerance to nitric oxide-induced DNA damage. Cancer Res. 2006;66(2):748-54.

18. Suzuki N, Yasui M, Geacintov NE, Shafirovich V, Shibutani S. Miscoding events during DNA synthesis past the nitration-damaged base 8nitroguanine. Biochemistry. 2005;44(25):9238-45.

19. Ma N, Murata M, Ohnishi S, Thanan R, Hiraku Y, Kawanishi S. 8-nitroguanine, a potential biomarker to evaluate the risk of inflammation-related carcinogenesis. In: Kahn TK, editor. Biomarker. Croatia: InTech; 2012. p. 201-24.

20. Ohnishi S, Ma N, Thanan R, Pinlaor S, Hammam O, Murata M, Kawanishi S. DNA damage in inflammation-related carcinogenesis and cancer stem cells. Oxid Med Cell Longev. 2013;2013:387014. doi:10.1155/2013/387014.

21. Ma N, Thanan R, Kobayashi H, Hammam O, Wishahi M, El Leithy T, Hiraku Y, Amro e-K, Oikawa S, Ohnishi S, Murata M, Kawanishi S. Nitrative DNA damage and Oct3/4 expression in urinary bladder cancer with Schistosoma haematobium infection. Biochem Biophys Res Commun. 2011:414(2):344-9. doi:10.1016/j.bbrc.2011.09.073. 
22. Thanan R, Murata M, Ma N, Hammam O, Wishahi M, El Leithy T, Hiraku Y, Oikawa S, Kawanishi S. Nuclear localization of COX-2 in relation to the expression of stemness markers in urinary bladder cancer. Mediators Inflamm. 2012;2012:165879. doi:10.1155/2012/165879.

23. Valent $\mathrm{P}$, Bonnet D, De Maria R, Lapidot T, Copland M, Melo JV, Chomienne C, Ishikawa F, Schuringa JJ, Stassi G, Huntly B, Herrmann H, Soulier J, Roesch A, Schuurhuis GJ, Wöhrer S, Arock M, Zuber J, Cerny-Reiterer S, Johnsen HE, Andreeff M, Eaves C. Cancer stem cell definitions and terminology: the devil is in the details. Nat Rev Cancer. 2012;12(11):767-75. doi:10.1038/nrc3368.

24. Thanan R, Ma N, lijima K, Abe Y, Koike T, Shimosegawa T, Pinlaor S, Hiraku Y, Oikawa S, Murata M, Kawanishi S. Proton pump inhibitors suppress iNOSdependent DNA damage in Barrett's esophagus by increasing Mn-SOD expression. Biochem Biophys Res Commun. 2012:421(2):280-5. doi:10.1016/j. bbrc.2012.03.152.

25. Hiraku Y, Kawanishi S, Ichinose T, Murata M. The role of iNOS-mediated DNA damage in infection- and asbestos-induced carcinogenesis. Ann N Y Acad Sci. 2010;1203:15-22. doi:10.1111/j.1749-6632.2010.05602.x.

26. Peek Jr RM, Blaser MJ. Helicobacter pylori and gastrointestinal tract adenocarcinomas. Nat Rev Cancer. 2002;2(1):28-37.

27. Helicobacter and Cancer Collaborative Group. Gastric cancer and Helicobacter pylori: a combined analysis of 12 case control studies nested within prospective cohorts. Gut. 2001;49(3):347-53.

28. Ohnishi N, Yuasa H, Tanaka S, Sawa H, Miura M, Matsui A, Higashi H, Musashi M, Iwabuchi K, Suzuki M, Yamada G, Azuma T, Hatakeyama M. Transgenic expression of Helicobacter pylori CagA induces gastrointestinal and hematopoietic neoplasms in mouse. Proc Natl Acad Sci U S A. 2008; 105(3):1003-8. doi:10.1073/pnas.0711183105.

29. Hashi K, Murata-Kamiya N, Varon C, Mégraud F, Dominguez-Bello MG, Hatakeyama M. Natural variant of the Helicobacter pylori CagA oncoprotein that lost the ability to interact with PAR1. Cancer Sci. 2014;105(3):245-51. doi:10.1111/cas.12342.

30. Posselt G, Backert S, Wessler S. The functional interplay of Helicobacter pylori factors with gastric epithelial cells induces a multi-step process in pathogenesis. Cell Commun Signal. 2013;11:77. doi:10.1186/1478-811X-11-77.

31. Ma N, Adachi Y, Hiraku Y, Horiki N, Horiike S, Imoto I, Pinlaor S, Murata M, Semba R, Kawanishi S. Accumulation of 8-nitroguanine in human gastric epithelium induced by Helicobacter pylori infection. Biochem Biophys Res Commun. 2004;319(2):506-10.

32. Fu S, Ramanujam KS, Wong A, Fantry GT, Drachenberg CB, James SP, Meltzer SJ, Wilson KT. Increased expression and cellular localization of inducible nitric oxide synthase and cyclooxygenase 2 in Helicobacter pylori gastritis. Gastroenterology. 1999;116(6):1319-29.

33. Sigal M, Rothenberg ME, Logan CY, Lee JY, Honaker RW, Cooper RL, Passarelli B, Camorlinga M, Bouley DM, Alvarez G, Nusse R, Torres J, Amieva MR. Helicobacter pylori activates and expands Lgr5(+) stem cells through direct colonization of the gastric glands. Gastroenterology. 2015;148(7): 1392-404.e21. doi:10.1053/j.gastro.2015.02.049.

34. Bessède $E$, Dubus $P$, Mégraud F, Varon C. Helicobacter pylori infection and stem cells at the origin of gastric cancer. Oncogene. 2015;34(20):2547-55. doi:10.1038/onc.2014.187.

35. IARC Working Group. Hepatitis C virus. In: IARC monographs on the evaluation of carcinogenic risks to humans vol.59. Lyon: IARC Press; 1994. p. 165-221.

36. Poynard T, Yuen MF, Ratziu V, Lai CL. Viral hepatitis C. Lancet. 2003; 362(9401):2095-100.

37. El-Serag HB. Epidemiology of viral hepatitis and hepatocellular carcinoma. Gastroenterology. 2012;142(6):1264-1273.e1. doi:10.1053/j.gastro.2011.12.061.

38. Karakasiliotis I, Mavromara P. Hepatocellular carcinoma: from hepatocyte to liver cancer stem cell. Front Physiol. 2015;6:154. doi:10.3389/fphys.2015.00154.

39. Horiike S, Kawanishi S, Kaito M, Ma N, Tanaka H, Fujita N, Iwasa M, Kobayashi Y, Hiraku Y, Oikawa S, Murata M, Wang J, Semba R, Watanabe S, Adachi Y. Accumulation of 8-nitroguanine in the liver of patients with chronic hepatitis C. J Hepatol. 2005;43(3):403-10.

40. McNaughton L, Puttagunta L, Martinez-Cuesta MA, Kneteman N, Mayers I, Moqbel R, Hamid Q, Radomski MW. Distribution of nitric oxide synthase in normal and cirrhotic human liver. Proc Natl Acad Sci U S A. 2002;99(26): 17161-6.

41. Rahman MA, Dhar DK, Yamaguchi E, Maruyama S, Sato T, Hayashi H, Ono T, Yamanoi A, Kohno H, Nagasue N. Coexpression of inducible nitric oxide synthase and COX-2 in hepatocellular carcinoma and surrounding liver: possible involvement of COX-2 in the angiogenesis of hepatitis C viruspositive cases. Clin Cancer Res. 2001;7(5):1325-32.
42. IARC. Cancers of the female reproductive organs. In: Stewart BW, Wild CP, editors. World Cancer Report. Geneva: WHO Press; 2014. p. 465-81.

43. Bosch FX, Manos MM, Muñoz N, Sherman M, Jansen AM, Peto J, Schiffman $\mathrm{MH}$, Moreno V, Kurman R, Shah KV. Prevalence of human papillomavirus in cervical cancer: a worldwide perspective. International biological study on cervical cancer (IBSCC) Study Group. J Natl Cancer Inst. 1995;87(11):796-802.

44. Tindle RW. Immune evasion in human papillomavirus-associated cervical cancer. Nat Rev Cancer. 2002;2(1):59-65.

45. IARC. Human papillomaviruses. In: IARC monographs on the evaluation of carcinogenic risks to humans, vol. 100B, a review of human carcinogens, part B: biological agents. Lyon: IARC Press; 2012. p. 261-319.

46. IARC. Human papillomaviruses. In: IARC monographs on the evaluation of carcinogenic risks to humans, vol 90. Lyon: IARC Press; 2007. p. 45-636.

47. Castle PE, Giuliano AR. Chapter 4: genital tract infections, cervical inflammation, and antioxidant nutrients-assessing their roles as human papillomavirus cofactors. J Natl Cancer Inst Monogr. 2003;31:29-34.

48. Marullo R, Werner E, Zhang H, Chen GZ, Shin DM, Doetsch PW. HPV16 E6 and E7 proteins induce a chronic oxidative stress response via NOX2 that causes genomic instability and increased susceptibility to DNA damage in head and neck cancer cells. Carcinogenesis. 2015;36(11):1397-406. doi:10.1093/carcin/bgv126.

49. Castle PE, Hillier SL, Rabe LK, Hildesheim A, Herrero R, Bratti MC, Sherman ME, Burk RD, Rodriguez AC, Alfaro M, Hutchinson ML, Morales J, Schiffman M. An association of cervical inflammation with high-grade cervical neoplasia in women infected with oncogenic human papillomavirus (HPV). Cancer Epidemiol Biomarkers Prev. 2001;10(10):1021-7.

50. Kulkarni S, Rader JS, Zhang F, Liapis H, Koki AT, Masferrer JL, Subbaramaiah K, Dannenberg AJ. Cyclooxygenase-2 is overexpressed in human cervical cancer. Clin Cancer Res. 2001;7(2):429-34.

51. Kim GE, Kim YB, Cho NH, Chung HC, Pyo HR, Lee JD, Park TK, Koom WS, Chun M, Suh CO. Synchronous coexpression of epidermal growth factor receptor and cyclooxygenase-2 in carcinomas of the uterine cervix: a potential predictor of poor survival. Clin Cancer Res. 2004;10(4):1366-74.

52. Hiraku Y, Tabata T, Ma N, Murata M, Ding X, Kawanishi S. Nitrative and oxidative DNA damage in cervical intraepithelial neoplasia associated with human papilloma virus infection. Cancer Sci. 2007;98(7):964-72.

53. Wei L, Gravitt PE, Song H, Maldonado AM, Ozbun MA. Nitric oxide induces early viral transcription coincident with increased DNA damage and mutation rates in human papillomavirus-infected cells. Cancer Res. 2009; 69(11):4878-84. doi:10.1158/0008-5472.CAN-08-4695.

54. López J, Ruíz G, Organista-Nava J, Gariglio P, García-Carrancá A. Human papillomavirus infections and cancer stem cells of tumors from the uterine cervix. Open Virol J. 2012;6:232-40. doi:10.2174/1874357901206010232.

55. Canham M, Charsou C, Stewart J, Moncur S, Hoodless L, Bhatia R, Cong D, Cubie H, Busby-Earle C, Williams A, McLoughlin V, Campbell JD, Cuschieri K, Howie S. Increased cycling cell numbers and stem cell associated proteins as potential biomarkers for high grade human papillomavirus + ve pre-neoplastic cervical disease. PLoS One. 2014;9(12):e115379. doi:10.1371/journal.pone.0115379.

56. Petersson F. Nasopharyngeal carcinoma: a review. Semin Diagn Pathol. 2015;32(1):54-73. doi:10.1053/j.semdp.2015.02.021.

57. Ma N, Kawanishi M, Hiraku Y, Murata M, Huang GW, Huang Y, Luo DZ, Mo WG, Fukui Y, Kawanishi S. Reactive nitrogen species-dependent DNA damage in EBV-associated nasopharyngeal carcinoma: the relation to STAT3 activation and EGFR expression. Int J Cancer. 2008;122(11):2517-25. doi:10.1002/ijc.23415.

58. Huang YJ, Zhang BB, Ma N, Murata M, Tang AZ, Huang GW. Nitrative and oxidative DNA damage as potential survival biomarkers for nasopharyngeal carcinoma. Med Oncol. 2011;28(1):377-84. doi:10.1007/s12032-010-9434-2.

59. Lo HW, Hsu SC, Ali-Seyed M, Gunduz M, Xia W, Wei Y, Bartholomeusz G, Shih JY, Hung MC. Nuclear interaction of EGFR and STAT3 in the activation of the iNOS/NO pathway. Cancer Cell. 2005;7(6):575-89.

60. Yang CF, Yang GD, Huang TJ, Li R, Chu QQ, Xu L, Wang MS, Cai MD, Zhong $L$, Wei HJ, Huang HB, Huang $J$, Qian CN, Huang BJ. EB-virus latent membrane protein 1 potentiates the stemness of nasopharyngeal carcinoma via preferential activation of PI3K AKT pathway by a positive feedback loop. Oncogene. 2015. doi:10.1038/onc.2015.402.

61. IARC. Schistosoma haematobium. In: IARC monographs on the evaluation of carcinogenic risks to humans "a review of human carcinogens: biological agents," vol. 100B. Lyon: IARC Press; 2012. p. 371-84.

62. Chen YC, Hsu HS, Chen YW, Tsai TH, How CK, Wang CY, Hung SC, Chang YL, Tsai ML, Lee YY, Ku HH, Chiou SH. Oct-4 expression maintained cancer stem-like properties in lung cancer-derived CD133-positive cells. PLoS One. 2008;3(7):e2637. doi:10.1371/journal.pone.0002637. 
63. Ponti D, Costa A, Zaffaroni N, Pratesi G, Petrangolini G, Coradini D, Pilotti S, Pierotti MA, Daidone MG. Isolation and in vitro propagation of tumorigenic breast cancer cells with stem/progenitor cell properties. Cancer Res. 2005; 65(13):5506-11.

64. Matsumura Y, Tarin D. Significance of CD44 gene products for cancer diagnosis and disease evaluation. Lancet. 1992;340(8827):1053-8.

65. Saito S, Okabe H, Watanabe M, Ishimoto T, Iwatsuki M, Baba Y, Tanaka Y Kurashige J, Miyamoto Y, Baba H. CD44v6 expression is related to mesenchymal phenotype and poor prognosis in patients with colorectal cancer. Oncol Rep. 2013;29(4):1570-8. doi:10.3892/or.2013.2273.

66. Kuncová J, Urban M, Mandys V. Expression of CD44s and CD44v6 in transitional cell carcinomas of the urinary bladder: comparison with tumour grade, proliferative activity and p53 immunoreactivity of tumour cells. APMIS. 2007;115(11):1194-205.

67. Yang YM, Chang JW. Bladder cancer initiating cells (BCICS) are among EMACD44v6+ subset: novel methods for isolating undetermined cancer stem (initiating) cells. Cancer Invest. 2008;26(7):725-33. doi:10.1080/07357900801941845.

68. Pinlaor S, Hiraku Y, Yongvanit P, Tada-Oikawa S, Ma N, Pinlaor P, Sithithaworn P, Sripa B, Murata M, Oikawa S, Kawanishi S. iNOS-dependent DNA damage via NF-kappaB expression in hamsters infected with Opisthorchis viverrini and its suppression by the antihelminthic drug praziquantel. Int J Cancer. 2006;119(5):1067-72.

69. Pinlaor S, Hiraku Y, Ma N, Yongvanit P, Semba R, Oikawa S, Murata M, Sripa B, Sithithaworn P, Kawanishi S. Mechanism of NO-mediated oxidative and nitrative DNA damage in hamsters infected with Opisthorchis viverrini: a model of inflammation-mediated carcinogenesis. Nitric Oxide. 2004;11(2):175-83.

70. Pinlaor S, Ma N, Hiraku Y, Yongvanit P, Semba R, Oikawa S, Murata M, Sripa B, Sithithaworn P, Kawanishi S. Repeated infection with Opisthorchis viverrini induces accumulation of 8-nitroguanine and 8-oxo-7,8-dihydro-2'deoxyguanine in the bile duct of hamsters via inducible nitric oxide synthase. Carcinogenesis. 2004;25(8):1535-42.

71. Pinlaor S, Sripa B, Ma N, Hiraku Y, Yongvanit P, Wongkham S, Pairojkul C, Bhudhisawasdi V, Oikawa S, Murata M, Semba R, Kawanishi S. Nitrative and oxidative DNA damage in intrahepatic cholangiocarcinoma patients in relation to tumor invasion. World J Gastroenterol. 2005;11(30):4644-9.

72. Thanan R, Murata M, Pinlaor S, Sithithaworn P, Khuntikeo N, Tangkanakul W, Hiraku Y, Oikawa S, Yongvanit P, Kawanishi S. Urinary 8-oxo-7,8-dihydro-2'deoxyguanosine in patients with parasite infection and effect of antiparasitic drug in relation to cholangiocarcinogenesis. Cancer Epidemiol Biomarkers Prev. 2008;17(3):518-24. doi:10.1158/1055-9965.EPI-07-2717.

73. Thanan R, Oikawa S, Yongvanit P, Hiraku Y, Ma N, Pinlaor S, Pairojkul C, Wongkham C, Sripa B, Khuntikeo N, Kawanishi S, Murata M. Inflammation-induced protein carbonylation contributes to poor prognosis for cholangiocarcinoma. Free Radic Biol Med. 2012;52(8):1465-72. doi:10.1016/j.freeradbiomed.2012.01.018.

74. Thanan R, Pairojkul C, Pinlaor S, Khuntikeo N, Wongkham C, Sripa B, Ma N, Vaeteewoottacharn K, Furukawa A, Kobayashi H, Hiraku Y, Oikawa S, Kawanishi S, Yongvanit P, Murata M. Inflammation-related DNA damage and expression of CD133 and Oct3/4 in cholangiocarcinoma patients with poor prognosis. Free Radic Biol Med. 2013;65:1464-72. doi:10.1016/j. freeradbiomed.2013.07.034.

75. Pinlaor S, Yongvanit P, Hiraku Y, Ma N, Semba R, Oikawa S, Murata M, Sripa B, Sithithaworn P, Kawanishi S. 8-nitroguanine formation in the liver of hamsters infected with Opisthorchis viverrini. Biochem Biophys Res Commun. 2003;309(3):567-71.

76. Katsurahara M, Kobayashi Y, Iwasa M, Ma N, Inoue H, Fujita N, Tanaka K, Horiki N, Gabazza EC, Takei Y. Reactive nitrogen species mediate DNA damage in Helicobacter pylori-infected gastric mucosa. Helicobacter. 2009; 14(6):552-8. doi:10.1111/j.1523-5378.2009.00719.x.

\section{Submit your next manuscript to BioMed Central and we will help you at every step:}

- We accept pre-submission inquiries

- Our selector tool helps you to find the most relevant journal

- We provide round the clock customer support

- Convenient online submission

- Thorough peer review

- Inclusion in PubMed and all major indexing services

- Maximum visibility for your research

Submit your manuscript at www.biomedcentral.com/submit
() BioMed Central 